\title{
The Complete Mitochondrial Genome of Gyps coprotheres (Aves, Accipitridae, Accipitriformes): Phylogenetic analysis of mitogenome among raptors
}

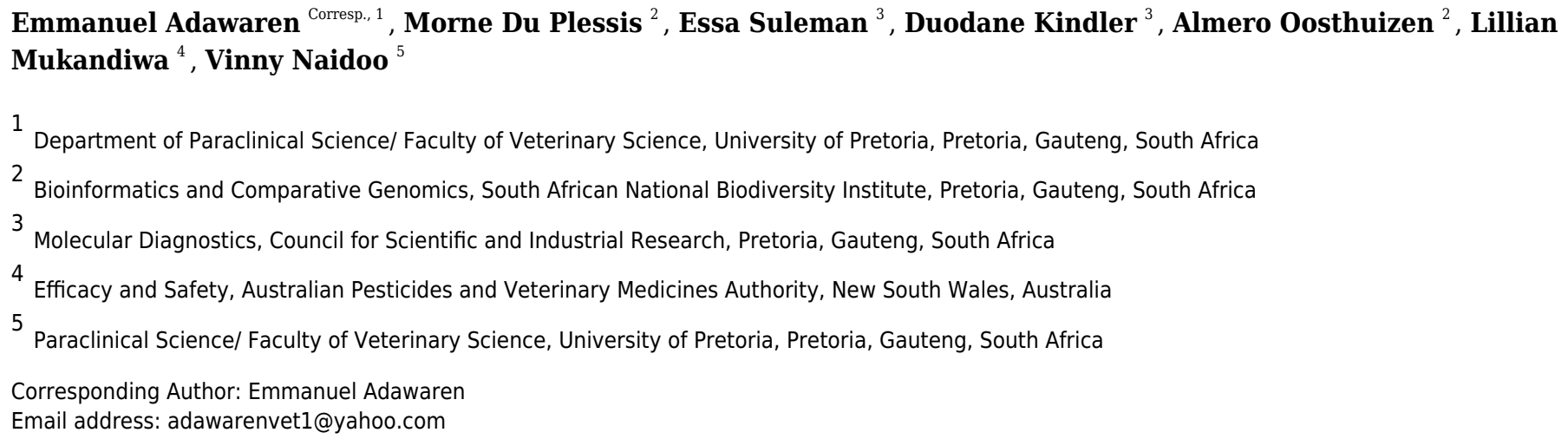

Three species of Old World vultures on the Asian peninsula are slowly recovering from the lethal consequences of diclofenac. At present the reason for species sensitivity to diclofenac is unknown. Furthermore, it has since been demonstrated that other Old World vultures like the Cape (Gyps coprotheres; CGV) and griffon (G. fulvus) vultures are also susceptible to diclofenac toxicity. Oddly, the New World Turkey vulture (Cathartes aura) and pied crow (Corvus albus) are not susceptible to diclofenac toxicity. As a result of the latter, we postulate an evolutionary link to toxicity. As a first step in understanding the susceptibility to diclofenac toxicity, we use the CGV as a model species for phylogenetic evaluations, by comparing the relatedness of various raptor species known to be susceptible, non-susceptible and suspected by their relationship to the Cape vulture mitogenome. This was achieved by next generation sequencing and assembly. The Cape vulture mitogenome had a genome size of $16908 \mathrm{bp}$. The mitogenome phylogenetic analysis indicated a close evolutionary relationship between Old World vultures and other members of the Accipitridae as indicated by bootstrap value of $100 \%$ on the phylogenetic trees. Based on this, we postulate that the other species could also be sensitive to the toxic effects of diclofenac. This warrants further investigations. 
1 The Complete Mitochondrial Genome of Gyps coprotheres (Aves, Accipitridae, 2 Accipitriformes): Phylogenetic analysis of mitogenome among raptors

3

4 Adawaren Emmanuel ${ }^{1}$, Du Plessis Morne $^{2}$, Suleman Essa $^{3}$, Kindler Duodane ${ }^{3}$, Oosthuizen 5 Almero ${ }^{2}$, Mukandiwa Lilian ${ }^{4}$, Naidoo Vinny ${ }^{1}$

6

$7{ }^{1}$ Department of Paraclinical Science, Faculty of Veterinary Science, University of Pretoria, Gauteng, SOUTH 8 AFRICA

9

10

${ }^{2}$ South African National Biodiversity Institute, Department of Bioinformatics and Comparative Genomics, Pretoria, 11 Gauteng, SOUTH AFRICA

12

13

14

${ }^{3}$ Council for Scientific and Industrial Research (CSIR), Department of Molecular Diagnostics, Pretoria, Gauteng SOUTH AFRICA

15

16

${ }^{4}$ Australian Pesticides and Veterinary Medicines Authority, Department of Efficacy and Safety, New South Wales, 17 AUSTRALIA

18

19 Corresponding author: Emmanuel Adawaren, adawarenvet1@yahoo.com; +27747749213

20

Faculty of Veterinary Science, Department of Paraclinical Science, University of Pretoria, Pretoria, South Africa 


\section{1. Abstract}

29 Three species of Old World vultures on the Asian peninsula are slowly recovering from the lethal consequences of diclofenac. At present the reason for species sensitivity to diclofenac is unknown.

31 Furthermore, it has since been demonstrated that other Old World vultures like the Cape (Gyps 32 coprotheres; CGV) and griffon (G. fulvus) vultures are also susceptible to diclofenac toxicity. 33 Oddly, the New World Turkey vulture (Cathartes aura) and Pied crow (Corvus albus) are not 34 susceptible to diclofenac toxicity. As a result of the latter, we postulate an evolutionary link to 35 toxicity. As a first step in understanding the susceptibility to diclofenac toxicity, we use the CGV as a model species for phylogenetic evaluations, by comparing the relatedness of various raptor species known to be susceptible, non-susceptible and suspected by their relationship to the Cape vulture mitogenome. This was achieved by next generation sequencing and assembly. The Cape vulture mitogenome had a genome size of $16908 \mathrm{bp}$. The mitogenome phylogenetic analysis indicated a close evolutionary relationship between Old World vultures and other members of the Accipitridae as indicated by bootstrap value of $100 \%$ on the phylogenetic trees. Based on this, we speculate that other species could also be sensitive to the toxic effects of diclofenac, which warrants further investigations.

Keywords: Cape vulture, Accipitridae, Phylogeny, Susceptibility, Diclofenac toxicity, 46 Cytochrome $\mathrm{C}$ oxidase 
53

54

55

56

57

58

59

60

61

62

63

64

65

66

67

68

69

70

71

72

73

74

75

76

77

78

79

80

81

82

83

\section{INTRODUCTION}

Generally, vultures may be classified as Old or New World vultures based on the apparent convergent evolutionary scavenging feeding habit (Seibold \& Helbig, 1995). However, in reality, they are a morphologically and evolutionary diverse group of birds (Seibold \& Helbig, 1995, Wink, 1995, Johnson et al., 2016). Old World vultures are descendants of the Accipitridae family, which also comprise eagles, hawks, kites and buzzards (Wink, 1995; Lerner \& Mindell, 2005; Clements et al., 2019). Old and New World vultures belong to two different families, Accipitridae and Cathartidae, respectively (Wink, 1995, Clemens et al., 2019). According to Clements' taxonomic classification, Accipitridae, which belongs to the order Accipitriformes, is one of the largest non-passerine families comprising 252 species (227 are monophyletic while 25 are polyphyletic) (Clements et al., 2019). The order Accipitriformes also includes the families Sagittariidae, Pandionidae and Cathartidae, although the latter is now classified under the order Cathartiformes (Wink, 1995; Clements et al., 2019).

Raptors are primarily predator birds that hunt and kill their prey but also include carrion feeders. These include members of the Accipitridae, Falconidae, Cathartidae, Strigidae and Tytonidae families (Clements et al., 2019). Raptors are valuable indicators of habitat quality based on their ecological sensitivity as predators and scavengers (Lerner \& Mindell, 2005). However, vultures belonging to the Accipitriformes order are currently facing devastating drops in their population numbers from an array of problems ranging from loss of their natural habitat, collision with high-tension electric cables and wind turbines, intentional poisoning of animal carcasses by poachers of endangered wildlife species and accidental ingestion of carcasses contaminated with pharmaceuticals (Ogada et al., 2016, Naidoo et al., 2017, Adawaren et al., 2018). One notable incident was the near complete extinction of three Gyps vulture species, the white-rumped vulture (Gyps bengalenesis), the Indian vulture ( $G$. indicus) and the slender-billed vulture ( $G$. tenuirostris) in India, Nepal and Pakistan from the consumption of carcasses of animals dosed with diclofenac (Oaks et al., 2004; Swan et al., 2006b; Naidoo et al., 2009a; Adawaren et al., 2018). At present, it is estimated that the drug caused the deaths of over 10 million vultures in the region (Naidoo et al., 2017). Furthermore, diclofenac has been implicated as the cause of death of a steppe eagle (Aquila nipalensis), a member of the Accipitridae family with classical sign of toxicity seen in vultures (Sharma et al., 2014). This incidence raises concern on the vulnerability of the Accipitriformes and other raptors to diclofenac toxicity. Complications due to the toxic 
84 consequences of diclofenac have also been reported in the Cape vulture (Swan et al., 2006b, 85 Naidoo et al., 2009b, Naidoo et al., 2010, Naidoo et al., 2017, Adawaren et al., 2018)

86

87

88

89

Diclofenac, a non-steroidal anti-inflammatory drug (NSAID) mostly understood for its analgesic, anti-inflammatory and an antipyretic characteristic, is used for the treatment of inflammatory disorders in humans and animals. The drug was, however, sufficient to cause death within 48 hours of exposure in vultures that had fed on the carcasses in which the drug was present, with signs of renal failure associated with visceral and articular gout being evident on necropsy (Oaks et al., 2004, Swan et al., 2006b, Naidoo, Swan, 2009). While the general mechanism of action of the NSAIDs and their toxicity in mammals is well characterized, the same cannot be said for vultures. Despite the exact cellular mechanism underlying toxicity remaining unknown, the clinical progression of toxicity is well established (Swan et al., 2006b, Naidoo et al., 2009a). Vultures generally show signs of depression as early as 24 hours after exposure (depression characterized by head drooping, reluctance to move, open wings, decreased appetite, loss of aggression, etc). At approximately 48 hours post exposure, the affected animals usually died, with post-mortem showing characteristic gross lesions of visceral and articular gout and histological lesions of renal tubular necrosis, especially the proximal convoluted tubules (PCT) of the kidney and hepatocytes of the liver (Swan et al., 2006b, Naidoo et al., 2009a). At the physiological level, the drug is associated with massive elevation in plasma uric acid amount, acidaemia, hyperkalaemia and increases in plasma liver enzyme activity. In terms of the temporal relationship, the first signs of depression correspond to the first elevation in uric acid amount indicative of early kidney damage, followed by increase in plasma liver enzyme activities indicative of hepatic necrosis, and, lastly, death associated with hyperkalaemia and acidosis. While speculative, the increase in potassium is purported to induce cardiac failure and death (Naidoo et al., 2007).

Following the discovery of diclofenac as the cause for these vulture deaths, research has shown that these Old World bird species are also vulnerable to other NSAIDs toxicity, with the notable exception being meloxicam thus far (Swan et al., 2006a, Naidoo et al., 2010, Adawaren et al., 2018). The scenario is, however, different with the New World vultures. In a study in which the Turkey vulture (Cathartes aura) was exposed to diclofenac $25 \mathrm{mg} / \mathrm{kg}$, a concentration that was 100 times above the median lethal dose $(0.1-0.2 \mathrm{mg} / \mathrm{kg})$ in Old World vultures, no overt toxicity was evident. Furthermore, the diclofenac could hardly be detected in the tissue after necropsy, with 
115 the concurrent pharmacokinetics study demonstrating a low plasma half-life of elimination of 6

116 hour, in comparison to 12-16 hours observed in Cape vultures (Rattner et al., 2008, Naidoo et al.,

117 2009a). The high sensitivity of the Old World vultures also contrasts with other bird species

118 whereby high doses in the region of $10 \mathrm{mg} / \mathrm{kg}$ was needed to induce toxicity in chickens (Gallus

119 gallus), with a corresponding plasma half-life elimination predicted within the range of 14 hours

120 in domestic chicken. The Pied crow (Corvus albus) was less sensitive with no signs of toxicity at

$12110 \mathrm{mg} / \mathrm{kg}$ and a plasma half-life of 2.5 hour (Naidoo et al., 2007, Naidoo et al., 2010).

122 Due to inter-species sensitivity and the apparent relationship between the plasma half-life

123 of elimination, it was suggested that the lethal effect of the NSAIDs in avian species is associated

124 with their ability to metabolise the drug in species-specific manner. From work in other species,

125 this limitations tends to be an evolutionary link in the Cytochrome P450 enzyme network, which

126 is responsible for xenobiotic metabolism. Naidoo et al (2010) postulated that toxicity in vultures

127 was due to zero-order metabolism related to a possible evolutionary pharmacogenetic defect in the

128 CYP2C family resulting in non-expression of the enzyme system, based on similar effects in

129 human with metabolic defects in the same enzyme family (Naidoo et al., 2010). As the CYP

130 enzyme of the vulture has yet to be identified. As CYP enzymes share an evolutionary link, we

131 speculate that species susceptible to toxicity are closely related, which might be visualized using

132 a phylogeny derived from complete mitogenomes (Bort et al., 1999, Goodman and Gilman, 2011,

133 Watanabe et al., 2013, Yang et al.,, 2016),

134 3. Materials and Methods

135 3.1. Materials

136

137

138

Sodium pentobarbital (Euthapent ${ }^{\circledR}$ ), ZR Genomic DNA Isolation kit (Zymo Research),

139 Technologies), liquid nitrogen (Afrox), $2 \mathrm{ml}$ cyrotubes (Greiner Bio-One, Frickenhausen) were

140 used in the study. The equipment used for the study were $-80^{\circ} \mathrm{C}$ refrigerator, NanoDrop

141 spectrophotometer (Thermo Fisher Scientific), microcentrifuge (Eppendorf), ION Torrent S5

142 (Thermo Fisher Scientific) Next Generation Sequencer, 540 ION chip (Thermo Fisher Scientific),

143 ABI 3130 Genetic Analyser (Applied Biosystems) and SimpliAmp Thermal Cycler (Thermo

144 Fisher Scientific).

Peer] reviewing PDF | (2019:11:43519:3:2:NEW 31 Aug 2020) 


\section{3.2. Methods}

\section{3.2.1. Publicly available sequence information}

147 The complete mitochondrial genomes $(m t D N A)$ of the bird species used for these studies were 148 obtained from GenBank. The species belonged to six families of raptors, namely, Accipitridae,

149 Pandionidae, Sagittariidae, Cathartidae, Falconidae and Strigidae respectively (Table 1).

$150 \quad 3.2 .2$. Collection of Skin Samples and Genomic DNA Extraction

151 This study was authorized by the Animal Ethics Committee of the University of Pretoria, South 152 Africa, with project numbers V093-15 and V097-17 in 2015 to 2017. Samples were 153 opportunistically collected immediately after the euthanasia of an individual Cape vulture (Gyps 154 coprotheres) with intravenous injection of pentobarbitone for a non-treatable physical injury. Skin 155 samples were stored in sterile cryotubes and placed immediately into liquid nitrogen $\left(-196^{\circ} \mathrm{C}\right)$ for 15610 minutes to snap-freeze the samples, which were then transferred into the $-80^{\circ} \mathrm{C}$ refrigerator 157 until genomic DNA extraction. The frozen Cape vulture skin samples were allowed to melt at 158 ambient temperature and approximately $25 \mathrm{mg}$ of the thawed tissue was excised for DNA 159 extraction using the ZR Genomic DNA Isolation kit (Zymo Research) according to manual 160 instructions. The quality of the extracted sample was examined using a NanoDrop reader.

\section{$161 \quad 3.2 .3$. Genome sequencing}

162 Genome sequencing was performed at the Uppsala Genome Centre, Uppsala University, 163 Uppsala, Sweden, on the ION S5 XL platform (Thermo Fisher. 2015). The genome sequencing 164 was conducted according to manual instruction. The run was performed on $200 \mathrm{bp}$ read length 165 chemistry on an ION-540 chip

\subsubsection{Mitogenome assembly and annotation}

The NGS sequence quality was evaluated using the FastQC software (Bioinformatics, 2011). Based on the quality assessment, the data was trimmed using the Trimmomatic program (Bolger et al., 2014) and the total dataset was down sampled to 10 million reads. Thereafter, reads

170 with lengths exceeding $100 \mathrm{bp}$ were selected for subsequent assembly. The de-novo assembly was

171 conducted using the CLC Genomic Workbench version 6.0 software on the default settings. The 172 subsequent assemblies were used to create a database against which a representative mitochondrial 
173 genome was queried. The contig with significant similarity to the query across its entire length 174 was then submitted to the MITOS server (Bernt et al., 2013) in order to perform annotation of the 175 mitochondrial genome.

\subsubsection{Mitogenome structure, organization and characterization of Gyps coprotheres}

177

178

179

180

181

182

183

184

185

186

187

188

189

190

191

192

193

194

195

196

197

198

199

200

The Cape vulture mitogenome order, organization and characterization were described as presented in Figure 1 and Table 2. Gene overlap and intergenic-space sequences were determined manually. The putative origin of light-strand replication $\left(\mathrm{O}_{\mathrm{L}}\right)$ and control region were identified by comparison with the homologous sequences of other bird species from the Accipitriformes order.

\subsubsection{Phylogenetics}

The mitogenome phylogeny was inferred using maximum likelihood analysis model in MEGA X between bird species included in this study (Hall, 2013). The raptor species included in the phylogenetic analysis belong to the Accipitridae, Falconidae, Strigidae and Cathartidae families while Strix leptogrammica was used as an outgroup (Fig.2). To determine the evolutionary relationship among the raptor bird species, each bird species complete mitogenome was analysed using the maximum likelihood method in MEGA X. The model test feature in MEGAX was used to evaluate the best-fit model of evolution, of which $\mathrm{GTR}+\mathrm{G}+\mathrm{I}$ was determined to be the best for constructing the phylogenetic tree. The preference model $\mathrm{GTR}+\mathrm{G}+\mathrm{I}$ was derived using the Molecular Evolutionary Genetic Analysis (MEGA) software by conducting DNA/Protein models analysis to determine the Disparity Index Test Pattern of heterogeneity of the aligned nucleotide sequences used for the construction of a maximum likelihood phylogenetic tree. This model was implemented in MEGAX to construct phylogenetic trees using the maximum likelihood algorithm by performing 1000 bootstrap replicates according to the protocol described by Hall (2013).

\section{Results}

\subsection{Mitogenome structure, organization and characterization of Gyps coprotheres}

The Cape vulture mitogenome is a 16908 bp circular DNA molecule with 13 protein coding genes (PCGs), 22 transfer RNA (tRNA), 2 ribosomal RNA (rRNA) and a non-coding region known as the D-loop (GenBank accession no. MF683387; Figure 1, Table 2). The most 
201 used start codon is ATG with 76.92\% frequency while ATA, GTG and ATT were alternate

202 initiation codons. On the other hand, TAA was the most used termination code with $53.85 \%$

203 frequency, while AGG and TAG served as alternate stop codons. Furthermore, NAD4 and COX3

204 do not have stop codons, but had T as their last nucleotide (Table 2). The architecture of the Cape

205 vulture $m t D N A$ was similar to those of the raptor bird species included in this study (Jiang et al., 206 2019).

2074.2.

208

209

210

211

212

213

214 2019).

215

216

217

218

219

220

221

222

223

224

225

226

227

228 2019).

\subsection{Phylogenetic analyses}

For this study, the evolutionary relationships among the bird species were investigated using phylogenetic analysis of the complete mitogenome among all the raptor species whose complete mitochondrial genome are available in GenBank. The choice of the mitogenomes as surrogates to investigate evolutionary relationships was because the mitogenome is composed of unique DNA sequences with evolutionary characteristic among animal species (Jiang et al., 2015;

\subsection{Discussion}

The phylogenetic trees inferred from the complete mitogenome sequences among the raptor bird species included in this study indicated a monophyletic relationship among the Accipitridae. These monophyletic relationships were presented as clusters of Buteo+Butastur, Accipiter+Circus Gyps+Aegypius+Spilornis and Nisaetus+Aquila clades, respectively, with $100 \%$ bootstrap values (Figure 2). Also the tree indicates that the Gyps species are closely related to Aegypius followed by Spilornis, Nisaetus, and Aquila genera respectively. Furthermore, the Pandion genus had close relationship to the Accipitridae followed by Sagittarius, Cathartes and the Falco genera, respectively (Johnson et al., 2016). In addition, the result showed a monophyletic relationship among falcons, which are closely related to Accipitridae compared to owls. The hierofalcons (Falco cherrug and Falco rusticolus) and Falco peregrinus cluster together into one clade with 100\% bootstrap support values (Figure 2). Furthermore, Falco tinnunculus and Falco naumanni had a monophyletic relationship with $100 \%$ bootstrap value, while Falco columbarius and Falco sparverius were outgroups. This study further confirmed the monophyletic relationship 
229 230 2018).

231

232 233 234 235

236

237

238

239

240

241

242

243

244

245

246

247

248

249

250

251

252

253

254

255

256

257

258

existing among falcons (Helbig et al., 1994, Wink et al., 2004, Nittinger et al., 2005, Doyle et al.,

Earlier pharmacokinetics studies of NSAIDs in Old World vultures and other bird species indicated that there is a species-specific relationship associated to NSAIDs toxicity among bird species (Swan et al., 2006b, Rattner et al., 2008, Naidoo et al., 2009a, Naidoo et al., 2010, Naidoo et al., 2011, Naidoo et al., 2017). In addition, the detrimental consequences of diclofenac have also been reported in the steppe eagle, a member of the Aquila genus (Sharma et al., 2014).

The phylogenetic analysis results (Figure 2) clustered the Old World vultures (Gyps and Aegypius genera), hawks (Nisaetus genus) and eagles (Spilornis and Aquila genera) into the same clade. Considering the susceptibility of Old World vulture eagle (Aquila nipalensis) species to diclofenac toxicity, it is possible that these closely-related bird species could also be sensitive to diclofenac toxicity (Figure 2). The hawk and eagle families are of more particular concern than the other members of Accipitridae. However hawks and eagles may also be somewhat more protected as a result of their feeding habits which solely rely on hunting and less commonly on carrion feeding as opposed to the Old World vultures which are purely carrion feeders i.e. the opportunity to be exposed to medicated carrions is higher for the vultures. Thus, it would be important to ascertain these species sensitivity as already undertaken in the pied crow and Turkey vultures. Based on this premise, the results also tend to suggest that falcons, owls, harries, bustards, buzzards, kestrels and hawks would be less likely susceptible to diclofenac, since they are an out grouping as seen with the Turkey vulture which is resistant to diclofenac at a dose that is 100 times the lethal dose seen in Old World vultures.

The possible reason for a shared susceptibility among Accipitridae may be explained by evolutionary changes in the cytochrome P450 (CYP) group of enzymes. These enzymes are important in the detoxification of environmental pollutants and xenobiotics (Bort et al., 1999, Goodman and Gilman, 2011, Watanabe et al., 2013). It thus stands to reason that, with the mitogenome indicating species similarity, these species would evolve under similar environmental conditions and thus develop similar CYP enzyme capacity. This was demonstrated with the cholinesterase enzyme system in which the concentrations in herbivores is naturally higher than carnivores, due to plants having higher concentrations of natural acetyl choline like substances in comparison to animals (Ruiz - Garcia et al., 2008). As a result, the evolutionary adaption of higher 
259

260

261

262

263

264

265

266

267

268

269

270

271

272

273

274

275

276

277

278

279

280

281

282

283

284

285

enzyme concentration of these enzyme results in herbivores being less susceptible to organophosphorus toxicity (Ruiz - Garcia et al., 2008).

Evolutionary variations in the CYP450 enzymes between diclofenac resistant bird species (Turkey vulture, pied crow, chicken) and susceptible Old World vultures can better explain species-specific toxicity observed among avian. It is therefore imperative to identify members of the CYP450 group of genes in birds to fully elucidate the reason behind resistance and susceptibility to NSAIDs.

\subsection{Conclusion}

The architecture of the Cape vulture mitogenome was similar to the raptor bird species included in this study. The mitogenome phylogenetic analyses suggest the possibility of sensitivity to diclofenac toxicity among hawks and eagles.

\subsection{Acknowledgements}

Kerri Wolter of VulPro is thanked for making the vulture tissue available. Sequencing was sponsored by Thermo Fisher Scientific (Mr Wayne Barnes). Emmanuel Adawaren was on a bursary sponsored by the National Research Foundation (NRF) of South Africa (Grant no 87772).

\subsection{References}

Adawaren, E.O., Mukandiwa, L., Njoya, E.M., Bekker, L., Duncan, N. \& Naidoo, V. 2018. The use of liver slices from the Cape vulture (Gyps coprotheres) to better understand the role of liver toxicity of non-steroidal anti-inflammatory drugs (NSAIDs) in vultures. Environmental Toxicology and Pharmacology 62: 147-155.

Bernt, M., Donath, A., Jühling, F., Externbrink, F., Florentz, C., Fritzsch, G., Pütz, J., Middendorf, M. \& Stadler, P.F. 2013. MITOS: Improved de novo metazoan mitochondrial genome annotation. Molecular Phylogenetics and Evolution 69: 313-319.

Bioinformatics, B. 2011, "FastQC: a quality control tool for high throughput sequence data. Cambridge, UK: Babraham Institute.

Bolger, A.M., Lohse, M. \& Usadel, B. 2014. Trimmomatic: a flexible trimmer for Illumina sequence data. Bioinformatics (Oxford, England) 30: 2114-2120. 
286 Bort, R., Macé, K., Boobis, A., Gómez-Lechón, M., Pfeifer, A. \& Castell, J. 1999. Hepatic

287

288

289

290

291

292

293

294

295

296

297

298

299

300

301

302

303

304

305

306

307

308

309

310

311

312

313 metabolism of diclofenac: role of human CYP in the minor oxidative pathways. Biochemical Pharmacology 58: 787-796.

Buermans, H. \& Den Dunnen, J. 2014,. Next generation sequencing technology: advances and applications. Biochimica et Biophysica Acta (BBA)-Molecular Basis of Disease: 1842: 19321941.

Clements, J.F., T.S. Schulenberg, M.J. Iliff, D. Roberson, T.A., Fredericks, B.L. Sullivan \& and C.L. Wood 2019, "The eBird/Clements checklist of birds of the world: Volume 3", [Online]. Available from: http://www.birds.cornell.edu/clementschecklist/download/.

Doyle, J.M., Katzner, T.E., Bloom, P.H., Ji, Y., Wijayawardena, B.K. \& DeWoody, J.A. 2014. The genome sequence of a widespread apex predator, the golden eagle (Aquila chrysaetos). PloS ONE 9: e95599.

Doyle JM, Bell DA, Bloom PH, Emmons G, Fesnock A, Katzner TE, LaPre L, Leonard K, SanMiguel P, Westerman R, DeWoody JA. 2018. New insights into the phylogenetics and population structure of the prairie falcon (Falco mexicanus). BMC Genomics 19: 233.

Goodman and Gilman 2011, The Pharmacological Basis of Therapeutics, 12th edn, Macmillan Press, Macmillan Administration, Houndmills, Basingstroke, Hampshire RG21, 2XS, UK.

Hall, B.G. 2013. Building phylogenetic trees from molecular data with MEGA. Molecular Biology and Evolution 30: 1229-1235.

Helbig AJ, Seibold I, Bednarek W, Gaucher P, Ristow D, Scharlau W, Schmidl D, Wink M. 1994. Phylogenetic relationships among Falcon species (genus Falco) according to DNA sequence variation of the cytochrome b gene. In: Meyburg B-U, Chancellor RC, editors. Raptor Conservation Today. Berlin: World Working Group Birds of Prey and Pica Press. :pp 593599.

Jiang, L., Chen, J., Wang, P., Ren, Q., Yuan, J., Qian, C., Hua, X., Guo, Z., Zhang, L. \& Yang, J. 2015. The mitochondrial genomes of Aquila fasciata and Buteo lagopus (Aves, Accipitriformes): sequence, structure and phylogenetic analyses: PloS one 10: e0136297. 
314 Jiang, L., Peng, L., Tang, M., You,Z., Zhang,M., West,A., Ruan,Q., Chen,W., Merilä, J. 2019.

315 Complete mitochondrial genome sequence of the Himalayan Griffon, Gyps himalayensis

316 (Accipitriformes: Accipitridae): Sequence, structure, and phylogenetic analyses Ecology and

317 Evolution 9: 8813-8828.

318 Johnson, J.A., Brown, J.W., Fuchs, J. \& Mindell, D.P. 2016. Multi-locus phylogenetic inference 319 among New World Vultures (Aves: Cathartidae). Molecular Phylogenetics and Evolution 320 105: 193-199.

321 Lerner, H.R. \& Mindell, D.P. 2005. Phylogeny of eagles, Old World vultures, and other 322 Accipitridae based on nuclear and mitochondrial DNA. Molecular Phylogenetics and Evolution. 37: 327-346.

Meteyer, C.U., Rideout, B.A., Gilbert, M., Shivaprasad, H. \& Oaks, J.L. 2005. Pathology and proposed pathophysiology of diclofenac poisoning in free-living and experimentally exposed

327

328

329

330

331

332

333

334

335

336 oriental white-backed vultures (Gyps bengalensis). Journal of Wildlife Diseases 41: 707-716.

Naidoo, V., Duncan, N., Bekker, L. \& Swan, G. 2007, "Validating the domestic fowl as a model to investigate the pathophysiology of diclofenac in Gyps vultures", Environmental Toxicology and Pharmacology 24: 260-266.

Naidoo, V., Taggart, M., Duncan, N., Wolter, K., Chipangura, J., Green, R. \& Galligan, T. 2017. The use of toxicokinetics and exposure studies to show that carprofen in cattle tissue could lead to secondary toxicity and death in wild vultures. Chemosphere.

Naidoo, V., Wolter, K., Cuthbert, R. \& Duncan, N. 2009a, "Veterinary diclofenac threatens Africa's endangered vulture species. Regulatory toxicology and pharmacology, vol. 53, no. 3, pp. 205-208.

Naidoo, V., Wolter, K., Cuthbert, R. \& Duncan, N. 2009b. Veterinary diclofenac threatens Africa's endangered vulture species. Regulatory Toxicology and Pharmacology 53: 205-208.

Naidoo, V. \& Swan, G.E. 2009. Diclofenac toxicity in Gyps vulture is associated with decreased uric acid excretion and not renal portal vasoconstriction. Comparative Biochemistry and Physiology Part C: Toxicology and Pharmacology 149: 269-274. 
341 Naidoo, V., Venter, L., Wolter, K., Taggart, M. \& Cuthbert, R. 2010. The toxicokinetics of 342 ketoprofen in Gyps coprotheres: toxicity due to zero-order metabolism. Archives of 343 Toxicology 84 10: 761-766.

344 Naidoo, V., Mompati, K.F., Duncan, N. \& Taggart, M.A. 2011, "The pied crow (Corvus albus) is

345

346

347

348

349

350

351

352

353

354

355

356

357

358

359

360

361

362

363

364

365

366

367

368

Oaks, J.L., Gilbert, M., Virani, M.Z., Watson, R.T., Meteyer, C.U., Rideout, B.A., Shivaprasad,

Nittinger F, Haring E, Pinsker W, Wink M, Gamauf A 2005. Out of Africa? Phylogenetic relationships between Falco biarmkus and the other hierofalcons (Aves: Falconidae)". Journal of Zoological Systematics and Evolutionary Research 43: 321-31. insensitive to diclofenac at concentrations present in carrion", Journal of Wildlife Diseases 47: 936-944.

H., Ahmed, S., Chaudhry, M.J.I. \& Arshad, M. 2004. Diclofenac residues as the cause of vulture population decline in Pakistan. Nature 427: 630-633.

Ogada, D.L, Keesing,F. \& Virani,M.Z. 2011. Dropping dead: causes and consequences of vulture population declines worldwide. Annals of the New York Academy of Sciences 1249: 57-71.

Ogada, D., Shaw, P., Beyers, R.L., Buij, R., Murn, C., Thiollay, J.M., Beale, C.M., Holdo, R.M., Pomeroy, D. \& Baker, N. 2016. Another continental vulture crisis: Africa's vultures collapsing toward extinction. Conservation Letters 9: 89-97.

Rattner, B.A., Whitehead, M.A., Gasper, G., Meteyer, C.U., Link, W.A., Taggart, M.A., Meharg, A.A., Pattee, O.H. \& Pain, D.J. 2008. Apparent tolerance of turkey vultures (Cathartes aura) to the non - steroidal anti - inflammatory drug diclofenac. Environmental Toxicology and Chemistry 27: 2341-2345.

Ruiz-Garcia, A., Bermejo, M., Moss, A. \& Casabo, V.G. 2008Pharmacokinetics in drug discovery. Journal of Pharmaceutical Sciences 97: 654-690.

Seibold, I. \& Helbig, A.J. 1995. Evolutionary history of New and Old World vultures inferred from nucleotide sequences of the mitochondrial cytochrome $\mathrm{b}$ gene. Philosophical transactions of the Royal Society of London.Series B, Biological Sciences 350: 163-178.

Sharma, A.K., Saini, M., Singh, S.D., Prakash, V., Das, A., Dasan, R.B., Pandey, S., Bohara, D., Galligan, T.H. \& Green, R.E. 2014. Diclofenac is toxic to the Steppe Eagle Aquila nipalensis: 
370

371

372

373

374

375

376

377

378

379

380

381

382

383

384

385

386

387

388

389

390

391

392

393

394

widening the diversity of raptors threatened by NSAID misuse in South Asia. Bird Conservation International 24: 282-286.

Slack, K.E., Delsuc, F., Mclenachan, P.A., Arnason, U. \& Penny, D. 2007. Resolving the root of the avian mitogenomic tree by breaking up long branches. Molecular Phylogenetics and Evolution 42: 1-13.

Slack, K.E., Janke, A., Penny, D. \& Arnason, U. 2003. Two new avian mitochondrial genomes (penguin and goose) and a summary of bird and reptile mitogenomic features. Gene 302: 4352.

Swan, G., Naidoo, V., Cuthbert, R., Green, R.E., Pain, D.J., Swarup, D., Prakash, V., Taggart, M., Bekker, L. \& Das, D. 2006a. Removing the threat of diclofenac to critically endangered Asian vultures. PLoS Biology 4: e66.

Swan, G.E., Cuthbert, R., Quevedo, M., Green, R.E., Pain, D.J., Bartels, P., Cunningham, A.A., Duncan, N., Meharg, A.A., Oaks, J.L., Parry-Jones, J., Shultz, S., Taggart, M.A., Verdoorn, G. \& Wolter, K. 2006b. Toxicity of diclofenac to Gyps vultures. Biology Letters 2; 279-282.

Watanabe, K.P., Kawai, Y.K., Ikenaka, Y., Kawata, M., Ikushiro, S., Sakaki, T. \& Ishizuka, M. 2013. Avian cytochrome P450 (CYP) 1-3 family genes: isoforms, evolutionary relationships, and mRNA expression in chicken liver. PloS ONE 8.

Wink, M. 1995. Phylogeny of Old and New World vultures (Aves: Accipitridae and Cathartidae) inferred from nucleotide sequences of the mitochondrial cytochrome $\mathrm{b}$ gene. Zeitschrift fur Naturforschung C-Journal of Biosciences 50: 868-882.

Wink M, Sauer-Gurth H, Ellis D, Kenward R. 2004 Phylogenetic relationships in the Hierofalco complex (Saker-, Gyr-, Lanner-, Laggar Falcon). In: Raptors Worldwide. pp. 499-504.

Yang, J., Ye, F. \& Huang, Y. 2016. Mitochondrial genomes of four katydids (Orthoptera: Phaneropteridae): New gene rearrangements and their phylogenetic implications. Gene 575: $702-711$. 
Figure 1

Complete mitochondrial genome organization and mitogene arrangement of Gyps coprotheres.

Genes found on the coding strand are indicated outside the mitochondrial genome map, while the mitogenes coded on the complementary strand are indicated inside the map. 


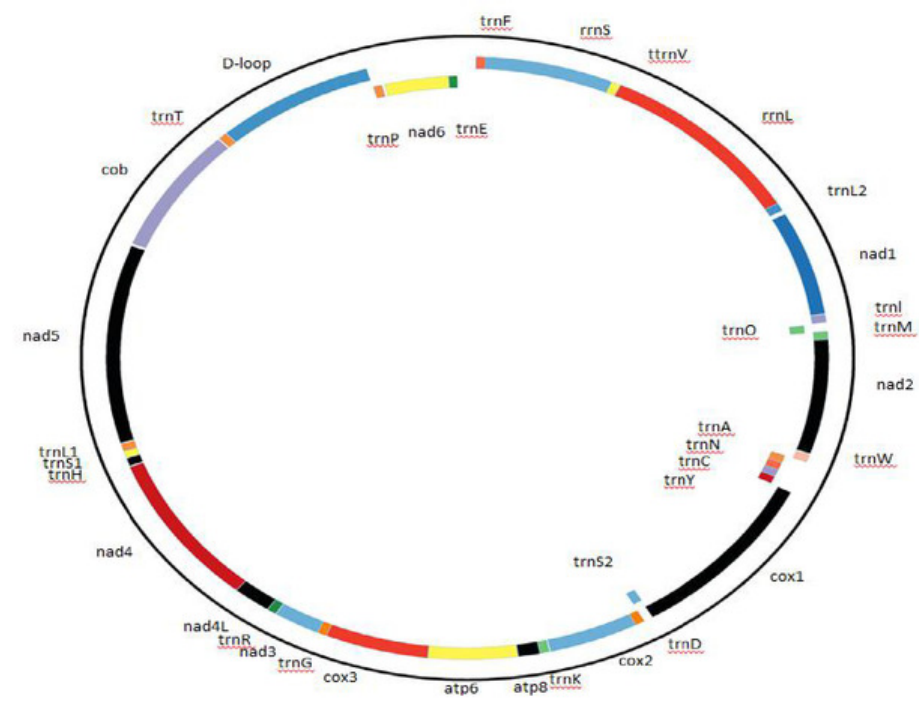




\section{Figure 2}

Phylogenetic Analysis Result using complete mitogenome

Results of Phylogenetic analyses using maximum likelihood (ML) analysis indicated evolutionary relationships among 33 raptor species based on complete mitogenome sequences. Strix leptogrammica was used as outgroup. Bootstrap support values for ML analyses are indicated on the nodes. The solid border rectangle indicates a close phylogenetic relationship between Old World vultures, Hawk and Eagles confirmed with high bootstrap values with greater chances of shared susceptibility based on their close evolutionary relationship. While distantly related raptor bird species are less likely to succumb to diclofenac toxicity as reported for Turkey vulture (Cathartes aura) (Rattner et al., 2008) 







\section{Table 1 (on next page)}

Mitogenome accession number and Diclofenac Toxicity Status of Bird Species investigated in this study as classified by Clements et al (2019).

(A) Bird species names, (B) Family name, (C) Accession number, (D) Genera Diclofenac toxicity status, (E) References 


\begin{tabular}{|c|c|c|}
\hline Species & Family & $\begin{array}{l}\text { Accession } \\
\text { number }\end{array}$ \\
\hline Accipiter gentilis (Northern Goshawk) & Accipitridae & NC_011818 \\
\hline Accipiter nisus (Eurasian Sparrowhawk) & Accipitridae & NC_025580 \\
\hline Accipiter soloensis (Chinese Sparrowhawk) & Accipitridae & KJ680303 \\
\hline Accipiter virgatus (Besra) & Accipitridae & NC_026082 \\
\hline Aegypius monachus (Cinereous Vulture) & Accipitridae & KF682364.1 \\
\hline Aquila chrysaetos (Golden Eagle) & Accipitridae & NC_024087 \\
\hline Aquila fasciata (Bonelli’s Eagle) & Accipitridae & KP329567 \\
\hline Aquila heliacal (Eastern imperial eagle) & Accipitridae & NC_035806 \\
\hline Buteo buteo (Common Buzzard) & Accipitridae & NC_003128 \\
\hline Buteo buteo burmanicus (Himalayan) & Accipitridae & KM364882 \\
\hline Buteo fasciatus (Bonelli’s eagle) & Accipitridae & NC_029188 \\
\hline Buteo hemilasius (Upland Buzzard) & Accipitridae & NC_029377.1 \\
\hline Buteo lagopus (Rough-legged Hawk) & Accipitridae & KP337337 \\
\hline Butastur indicus (Grey-faced Buzzard) & Accipitridae & NC_032362 \\
\hline Butastur liventer (Rufous-wing Buzzard) & Accipitridae & AB830617 \\
\hline Cathartes aura (Turkey Vulture) & Cathartidae & NC_007628 \\
\hline circus cyaneus (Northern Harrier) & Accipitridae & KX925606 \\
\hline circus melanoleucos (Pied Harrier) & Accipitridae & NC_035801 \\
\hline Gyps coprotheres (Cape vulture) & Accipitridae & MF683387 \\
\hline Gyps fulvus (Griffon vulture) & Accipitridae & NC_036050 \\
\hline Gyps himalayensis (Himalayan vulture) & Accipitridae & KY594709.1 \\
\hline Nisaetus alboniger (Blyth's Hawk-Eagle) & Accipitridae & NC_007599 \\
\hline Nisaetus nipalensis (Mountain Hawk-Eagle) & Accipitridae & NC 007598.1 \\
\hline Spilornis cheela (Crested Serpent-Eagle) & Accipitridae & NC_015887 \\
\hline Sagittarius serpentarius (Secretary-bird) & Sagittariidae & $\mathrm{NC} 023788$ \\
\hline
\end{tabular}




\begin{tabular}{|l|l|l|}
\hline Pandion haliaetus (Osprey) & Pandionidae & NC_008550 \\
\hline Strix leptogrammica (Brown wood owl) & Strigidae & KC953095.1 \\
\hline Falco columbarius (Merlin) & Falconidae & KM264304.1 \\
\hline Falco tinnunculus (Common Kestrel) & Falconidae & EU196361.1 \\
\hline Falco sparverius (American kestrel) & Falconidae & DQ780880.1 \\
\hline Falco naumanni (Lesser Kestrel) & Falconidae & KM251414.1 \\
\hline Falco peregrinus (Barbary falcon) & Falconidae & JQ282801.1 \\
\hline Falco cherry (Cherry Falcon) & Falconidae & KP337902.1 \\
\hline Falco rusticolus (Gyrfalcon) & Falconidae & KT989235.1 \\
\hline
\end{tabular}

1 


\section{Table 2 (on next page)}

Characteristics of the mitochondrial genome of Gyps coprotheres

(A) Mitogene names, (B) mitogene position, (C) Mitogene nucleotide size, (D) Mitogene start and stop codon, (E) Mitogene intergenic overlap, (F) Mitogene strand, (G) Mitogene A+T\% nucleotide composition 


\begin{tabular}{|c|c|c|c|c|c|c|c|c|}
\hline \multirow[t]{2}{*}{ Gene } & \multicolumn{2}{|c|}{ Position } & \multirow{2}{*}{$\begin{array}{l}\text { Size } \\
\begin{array}{l}\text { Nucleotid } \\
\text { e }\end{array}\end{array}$} & \multicolumn{2}{|c|}{ Condon } & \multirow{2}{*}{$\begin{array}{l}\text { Intergenic } \\
\text { overlap }\end{array}$} & \multirow[t]{2}{*}{ Strand } & \multirow{2}{*}{$\begin{array}{l}\begin{array}{l}\text { Nucleotide } \\
\text { composition }\end{array} \\
\mathrm{A}+\mathrm{T} \%\end{array}$} \\
\hline & From & To & & Start & Stop & & & \\
\hline tRNA-Phe & 1 & 70 & 70 & & & 0 & $\mathrm{H}$ & 47.2 \\
\hline $12 \mathrm{~S}$ rRNA & 70 & 1037 & 968 & & & 0 & $\mathrm{H}$ & 51.2 \\
\hline tRNA-Val & 1037 & 1108 & 72 & & & 0 & $\mathrm{H}$ & 55.6 \\
\hline 16S rRNA & 1109 & 2709 & 1601 & & & 1 & $\mathrm{H}$ & 54 \\
\hline tRNA-Leu & 2710 & 2783 & 74 & & & 1 & $\mathrm{H}$ & 47.3 \\
\hline ND1 & 2822 & 3800 & 978 & ATG & AGG & 39 & $\mathrm{H}$ & 53.9 \\
\hline tRNA-Ile & 3769 & 3840 & 72 & & & -31 & $\mathrm{H}$ & 55.5 \\
\hline tRNA-Gln & 3854 & 3924 & 71 & & & 14 & $\mathrm{~L}$ & 67.6 \\
\hline tRNA-Met & 3924 & 3992 & 69 & & & 0 & $\mathrm{H}$ & 49.3 \\
\hline ND2 & 3993 & 5039 & 1047 & ATG & TAG & 1 & $\mathrm{H}$ & 52.6 \\
\hline tRNA-Trp & 5038 & 5109 & 72 & & & -1 & $\mathrm{H}$ & 62.5 \\
\hline tRNA-Ala & 5111 & 5179 & 69 & & & 2 & $\mathrm{~L}$ & 56.5 \\
\hline tRNA-Asn & 5182 & 5254 & 73 & & & 3 & $\mathrm{~L}$ & 50.7 \\
\hline tRNA-Cys & 5257 & 5323 & 67 & & & 3 & $\mathrm{~L}$ & 49.3 \\
\hline tRNA-Tyr & 5324 & 5393 & 70 & & & 1 & $\mathrm{~L}$ & 55.7 \\
\hline COX1 & 5395 & 6945 & 1551 & GTG & AGG & 2 & $\mathrm{H}$ & 52.8 \\
\hline tRNA-Ser & 6937 & 7010 & 74 & & & -8 & $\mathrm{~L}$ & 52.7 \\
\hline tRNA-Asp & 7015 & 7083 & 69 & & & 5 & $\mathrm{H}$ & 59.4 \\
\hline COXII & 7086 & 7769 & 684 & ATG & TAA & 3 & $\mathrm{H}$ & 52.8 \\
\hline tRNA-Lys & 7771 & 7841 & 71 & & & 2 & $\mathrm{H}$ & 59.1 \\
\hline ATP8 & 7843 & 8010 & 168 & ATG & TAA & 2 & $\mathrm{H}$ & 55.6 \\
\hline ATP6 & 8001 & 8684 & 684 & ATG & TAA & -9 & $\mathrm{H}$ & 54.8 \\
\hline COXIII & 8684 & 9467 & 784 & ATG & $\mathrm{T}$ & 0 & $\mathrm{H}$ & 52.9 \\
\hline tRNA-Gly & 9468 & 9536 & 69 & & & 1 & $\mathrm{H}$ & 66.6 \\
\hline
\end{tabular}




\begin{tabular}{|c|c|c|c|c|c|c|c|c|}
\hline ND3 & 9537 & 9710 & 351 & ATT & TAA & 1 & $\mathrm{H}$ & 55.1 \\
\hline tRNA-Arg & 9893 & 9961 & 69 & & & 183 & $\mathrm{H}$ & 59.4 \\
\hline ND4L & 9963 & 10259 & 297 & ATG & TAA & 2 & $\mathrm{H}$ & 53.9 \\
\hline ND4 & 10253 & 11630 & 1378 & ATG & $\mathrm{T}$ & -6 & $\mathrm{H}$ & 51.3 \\
\hline tRNA-His & 11631 & 11700 & 70 & & & 1 & $\mathrm{H}$ & 65.7 \\
\hline tRNA-Ser & 11702 & 11766 & 65 & & & 2 & $\mathrm{H}$ & 55.4 \\
\hline tRNA-Leu & 11767 & 11837 & 71 & & & 1 & $\mathrm{H}$ & 62.0 \\
\hline ND5 & 11847 & 13652 & 1806 & ATA & TAA & 10 & $\mathrm{H}$ & 55.2 \\
\hline Cytb & 13665 & 14807 & 1143 & ATG & TAA & 13 & $\mathrm{H}$ & 52.3 \\
\hline tRNA-Thr & 14810 & 14877 & 68 & & & 3 & $\mathrm{H}$ & 64.8 \\
\hline tRNA-Pro & 16083 & 16152 & 70 & & & 1206 & $\mathrm{~L}$ & 61.4 \\
\hline ND6 & 16174 & 16692 & 519 & ATG & TAG & 22 & $\mathrm{H}$ & 50.3 \\
\hline tRNA-Glu & 16693 & 16763 & 71 & & & 1 & $\mathrm{~L}$ & 62.0 \\
\hline D-loop & 14878 & 16082 & 4 & & & -1885 & $\mathrm{H}$ & 58.6 \\
\hline $\begin{array}{l}\text { Unknown } \\
\text { Region }\end{array}$ & 16764 & 16908 & 145 & & & 682 & $\mathrm{H}$ & 62.7 \\
\hline
\end{tabular}

